\title{
Comparison of Angiotensin Converting Enzyme Inhibitors and Beta Blockers in Prevention of Atrial Fibrillation Recurrences After Electrical Cardioversion
}

\author{
Elektriksel Kardiyoversiyon Sonrasında Atriyal Fibrilasyon Nükslerinin Önlenmesinde Anjiyotensin Dönüştürücü Enzim \\ Inhibitörleri ve Beta Blokerlerin Karşılaştırılması
}

\author{
Timuçin Altın, Adalet Gürlek, Çağdaş Özdöl, Mustafa Kılıçkap, İrem Dinçer, \\ Sibel Turhan, Çetin Erol
}

Ankara Üniversitesi Tip Fakültesi, Kardiyoloji AD.

Aim: Angiotensin-converting enzyme (ACE) inhibitors and beta blockers were shown to be effective in prevention of atrial fibrillation (AF) recurrences after electrical cardioversion, by interfering with atrial structural and electrical remodeling. In this study, we aimed to compare the effects of ACE inhibitor cilazapril and beta blocker metoprolol after cardioversion of AF in terms of sinus rhythm maintenance.

Patients and Methods: The study population comprised 120 patients with persistent atrial fibrillation (>7 days) who underwent successful cardioversion. Randomization into 3 groups was done after successful cardioversion. Group I $(n=41)$ was treated with amiodarone, group II $(n=41)$ was treated with amiodarone plus metoprolol, and group III $(n=38)$ was treated with amiodarone plus cilazapril. The primary end-point of the study was the recurrence rates between groups at one year and with those who recurred, the time to recurrence of AF.

Results: After 1 year follow-up, maintenance of sinus rhythm were similar among groups (KaplanMeier analysis, $24 \%, 37 \%$ and $26 \%$ respectively; log rank $=0.3$ ). There was no difference among groups with respect to time to recurrence of AF.

Conclusion: Patients treated with amiodarone only, amiodarone plus metoprolol and amiodarone plus cilazapril had similar rates of recurrence of AF.

Key Words: Atrial fibrillation, cardioversion, angiotensin-converting enzyme inhibitors, beta blockers

Amaç: Atriyal fibrilasyonun (AF) elektriksel kardiyoversiyonu sonrasında, anjiyotensin dönüştürücü enzim (ACE) inhibitörleri ve beta blokerlerin atriyal yapısal ve elektriksel remodeling' $i$ azaltmak suretiyle AF nükslerini azalttığı gösterilmiştir. Bu çalışmada, kardiyoversiyon sonrasında ACE inhibitörü cilazapril ve beta bloker metoprolol' ün sinüs ritmi idamesindeki etkileri karşılaştırıldı.

Hastalar ve Yöntem: Çalışmaya persistan AF'si olup başarılı kardiyoversiyon yapılan 120 hasta alındı. Kardiyoversiyon sonrasında hastalar 3 gruba randomize edildi. Grup I'e ( $n=41)$ amiodaron, Grup II'ye ( $n=41)$ amiodaron+metoprolol, Grup III' e $(n=38)$ amiodaron+cilazapril verildi. Çalışmanın primer sonlanım noktası $\mathrm{AF}$ nüks oranları ve $\mathrm{AF}$ nüksü görülenlerde nükse kadar geçen zaman idi.

Bulgular: Bir yıllık takip sonunda gruplar arasında sinüs ritmi idamesi arasında anlamlı fark saptanmadı (Kaplan Meier analizi, sırasıyla \%24, \%37 and \%26; log rank=0.3). AF nüks zamanları açısından da gruplar arasında fark gözlenmedi.

Sonuç: Amiodaron, amiodaron+metoprolol veya amiodaron+cilazapril tedavilerinin AF nüksü üzerine etkileri benzer bulunmuştur.

Anahtar Kelimeler: Atriyal fibrilasyon, kardiyoversiyon, anjiyotensin dönüştürücü enzim inhibitörleri, beta blokerler

Received: 07.09.2007 - Accepted: 29.01.2008

Corresponding author

Timuçin Altın

Ankara Üniversitesi Tıp Fakültesi, Kardiyoloji AD.

Phone

E-mail address : alitimaltin@yahoo.com
Atrial fibrillation (AF) is a common arrhythmia in clinical practice, and may result in serious complications (1). Direct current cardioversion of persistent $\mathrm{AF}$ is the most effective treatment for the resto- ration of sinus rhythm but it may be hampered by high recurrence rates (2).

One of the accepted mechanisms of $\mathrm{AF}$ recurrence is electrical and 
structural remodelling caused by changes in the refractory period of the atrial muscle and atrial fibrosis with intraatrial conduction disturbances (3). Renin-angiotensin system (RAS) leads to cardiac fibrosis via increased angiotensin II and aldosteron levels in a variety of cardiac disorders (4). Three-fold increase in angiotensin-converting enzyme (ACE) expression occurs in chronic persistent AF (5), and several studies reported the relationship between increased angiotensin II levels and arrhythmogenic atrial electrical and structural remodeling that could be reversed by blockade of the RAS (6-9).

Abnormal autonomic control is another mechanism that was suggested to increase AF recurrence. Increased adrenergic and reduced vagal stimulation contribute to atrial electrical remodeling by facilitating intracellular calcium overload (10). Intracellular calcium lowering drugs (beta blockers and calcium channel blockers) (11) and beta blockers $(12,13)$ were found to be effective in reduction of $\mathrm{AF}$ recurrences after cardioversion.

Up to our knowledge, there is no prospective study comparing the effect of ACE inhibitors and beta blockers on $\mathrm{AF}$ recurrence rates after electrical cardioversion. In the present study, we aimed to investigate whether the ACE inhibitor cilazapril or the beta blocker metoprolol add benefit on the antiarrhythmic drug amiodarone and to compare the effects of these drugs in terms of maintaining sinus rhythm after electrical cardioversion of AF.

\section{Methods}

The study population comprised 120 patients with persistent atrial fib- rillation ( $>7$ days) who underwent successful cardioversion between December 2002 and February 2005. During this time period a total of 205 patients reffered to our clinic for electrical cardioversion were screened and 85 of them were excluded. The reasons were: Presence of thrombus in the left atrium (14 patients), unsuccessful cardioversion (26 patients), unwilling to participate (5 patients) and presence of one of the exclusion criteria listed below (40 patients).

Exclusion criteria included a left atrium size $>6 \mathrm{~cm}$, acute coronary syndrome within 6 weeks, known thyroid, hepatic or pulmonary disease, heart surgery within 6 weeks, contraindications to treatment with amiodarone, beta-blockers or ACE-inhibitors, heart failure (NYHA class III-IV), rheumatic valve disease, paroxysmal atrial fibrillation, known allergy to amiodarone, beta-blockers or ACE-inhibitors.

Written informed consent was obtained from all patients before they entered the study. All patients clinical history, physical examination, TSH measurements and transthoracic echocardiograms were done and scheluded for transoesophegeal echocardiography (TEE). Patients were asked to withdraw ACE inhibitors and/or betablockers 1 week before TEE. Those with hypertension, amlodipin was initiated. After TEE demostrated no visible thrombus in the left atrium, cardioversion was done in the same day. Patients who were not previously anticoagulated started both warfarin and heparin infusion. The infusion was stopped when the international normalized ration $($ INR) $>2$. Cardioversion was performed with a biphasic defibrillator (HeartStart XL, Philips). Successful cardioversion was defined as sinus rhythm recovery lasting as least 1 minute after the shock. Anticoagulation was continued for at least 4 weeks after electrical cardioversion.

Randomization into 3 groups was done after successful cardioversion: Group I: Amiodarone (Cordarone, Sanofi-Synthelabo) only group (900mg IV infusion just after the shock for 24 hours, followed by oral amidarone $200 \mathrm{mg}$ three times a day for one week, two times a day for subsequent week and thereafter daily $200 \mathrm{mg}$ maintenance dose); Group II: Amiodarone plus metoprolol ( Beloc, Astra-Zeneca) (50mg/day which could be increased to $100 \mathrm{mg} /$ day) and Group III: Amiodarone plus cilazapril (Inhibace, Roche) ( $5 \mathrm{mg}$ /day which could be increased to $10 \mathrm{mg} /$ day in hypertensive patients). The drugs were given in an open label fashion. Patients were not allowed to use ACE-inhibitors, angiotensin receptor blockers or beta-blockers other than the assigned treatment. If the patient had high blood pressure amlodipin was initiated.

Patients were examined at 1, 3, 6 and 12 months, and at any time the patient complained of palpitations or any other symptoms. Standard 12-lead ECG and inquiry about any recurence of palpitation was done at each visit. The cardiologist who assessed the outcome was blinded for the patient's group assignment.

The primary end-point of the study was the comparison of recurrence rates between groups at one year and with those who recurred, the time to recurrence of AF.

\section{Statistical Analysis:}

Statistical analyses were performed 
using SPSS 10.0 (version 10.0 for Windows, SPSS Inc., Chicago, Illinois). Data are expressed as numbers and percentages for discrete variables and as means $\pm \mathrm{SD}$ for continuous variables. Comparisons between groups were performed by univariate analysis with the one-way ANOVA or KruskalWallis analysis of variance test for the continuous variables and by using chi-square test for the other parameters. Estimates of the proportion of patients remaining in sinus rhythm over time were constructed using the method of Kaplan-Meier and compared with log rank test. Results with a $\mathrm{p}$ value less than 0.05 were considered significant.

\section{Results}

The study population consisted 120 patients with persistent atrial fibril- lation who underwent successful cardioversion (mean age: $62 \pm 12$ years, 50 were male). The baseline demographic and clinical characteristics of the groups were given in Table 1. As noted, groups were similar, whereas diabetes mellitus prevelance and pulmonary artery pressure were tended to be lower in group I (Table 1). The mean duration of $\mathrm{AF}$ before randomization was 19 months, with no differences among the groups. As shown in table 1, the groups were similar with regard to all concomitant medications.

At the 1st month follow-up visit, 10 patients had a recurrence of AF (4 patients in group I, 3 patients in group II, and 3 patients in group III, $\mathrm{p}=0.9)$. The proportion of patients with sinus rhythm at 3 rd and 6th months follow-up were also similar (Table 2). After a median follow-up period of 12 months, Kaplan-Meier analysis (Figure 1) showed that maintanence of sinus rhythm between groups did not differ (Kaplan-Meier analysis,

Table 1: Characteristics of the patients

\begin{tabular}{|c|c|c|c|c|}
\hline & $\begin{array}{c}\text { Group I } \\
n=41\end{array}$ & $\begin{array}{c}\text { Group II } \\
n=41\end{array}$ & $\begin{array}{c}\text { Group III } \\
n=38\end{array}$ & $\mathbf{p}$ \\
\hline Age, years & $62 \pm 13$ & $63 \pm 11$ & $61 \pm 11$ & 0.8 \\
\hline Male, n (\%) & $16(39)$ & $16(39)$ & $18(47)$ & 0.7 \\
\hline $\begin{array}{l}\text { Underlying heart disease, n (\%) } \\
\text { Coronary artery disease } \\
\text { Mitral valve disease } \\
\text { Hypertension } \\
\text { Dilated CMP } \\
\text { Other }\end{array}$ & $\begin{array}{l}20(48) \\
13(32) \\
4(10) \\
2(5) \\
2(5)\end{array}$ & $\begin{array}{c}12(29) \\
13(32) \\
12(29) \\
2(5) \\
2(5)\end{array}$ & $\begin{array}{l}10(26) \\
11(29) \\
7(18) \\
7(18) \\
3(9)\end{array}$ & 0.1 \\
\hline Body mass index, $\mathrm{kg} / \mathrm{m}^{2}$ & $25 \pm 3.4$ & $27 \pm 4.3$ & $27 \pm 3.2$ & 0.7 \\
\hline Diabetes mellitus, n (\%) & $5(12)$ & $11(27)$ & $10(26)$ & 0.2 \\
\hline Smoking, n (\%) & $6(15)$ & $2(5)$ & $6(16)$ & 0.2 \\
\hline Left atrial diameter, $\mathrm{mm}$ & $5 \pm 0.6$ & $4.9 \pm 0.7$ & $4.7 \pm 0.8$ & 0.1 \\
\hline $\mathrm{PAP}, \mathrm{mmHg}, \mathrm{n}(\%)$ & $35 \pm 5$ & $46 \pm 16$ & $43 \pm 8$ & 0.3 \\
\hline Duration of AF, months, n (\%) & $18 \pm 8$ & $21 \pm 10$ & $19 \pm 11$ & 0.3 \\
\hline $\begin{array}{l}\text { Concomitant medications, } \mathrm{n}(\%) \\
\text { Digoxin } \\
\text { CCB } \\
\text { Diuretics } \\
\text { Anticoagulant drugs } \\
\text { Aspirin }\end{array}$ & $\begin{array}{c}5(12) \\
6(15) \\
2(5) \\
41(100) \\
20(48) \\
\end{array}$ & $\begin{array}{c}1(3) \\
4(10) \\
1(3) \\
41(100) \\
12(29) \\
\end{array}$ & $\begin{array}{c}4(11) \\
1(3) \\
1(3) \\
38(100) \\
12(32) \\
\end{array}$ & $\begin{array}{l}0.3 \\
0.2 \\
0.8 \\
1 \\
0.1\end{array}$ \\
\hline Number of shocks & $2.4 \pm 0.5$ & $1.7 \pm 0.8$ & $1.7 \pm 0.9$ & 0.3 \\
\hline
\end{tabular}

AF, atrial fibrillation; CCB, calcium channel blockers; CMP, cardiomyopathy; PAP, pulmonary arterial pressure. 
Table 2: End-points

\begin{tabular}{|c|c|c|c|}
\hline & Group I & Group II & Group III \\
\hline Sinus rhythm at 1 month, $n$ & 37 & 38 & 35 \\
\hline Sinus rhythm at 3 month, $n$ & 31 & 33 & 31 \\
\hline Sinus rhythm at 6 month, $n$ & 19 & 25 & 25 \\
\hline Sinus rhythm at end of follow up, $n$ & 10 & 15 & 10 \\
\hline Months to recurrence & $5 \pm 3$ & $5.8 \pm 3.6$ & $6.3 \pm 3.4$ \\
\hline Heart rate at the end of follow-up,bpm* & $68 \pm 11$ & $63 \pm 7$ & $70 \pm 9$ \\
\hline $\begin{array}{l}\text { Withdrawn because of adverse effect at the end of } \\
\text { follow up, } n\end{array}$ & 4 & 8 & 5 \\
\hline
\end{tabular}

${ }^{*} \mathrm{p}=0.004$

$76 \%, 63 \%$ and $74 \%$ respectively; $\log$ rank $=0.3$ ).

Adverse clinical events resulted in discontinuation in 4 patients (10\%) treated with amiodarone, 8 patients $(20 \%)$ treated with amiodarone plus metoprolol and 5 (13\%) patients treated with amiodarone plus cilazapril (Table 2). Three patients discontinued cilazapril because of dry cough, one patient because of elevated potassium levels. Discontinuation of amiodarone occured in 4 patients in group I, 3 patients in group II and 1 patient in group III. The reasons were: thyroid pathologies (4 patients), gastrointestinal events ( 2 patients) and elevation of liver enzymes ( 2 patients). Five patient discontinued metoprolol because of symptomatic bradycardia in group II. None of the patients died during the study period and no thrombo-embolic events occured.

\section{Discussion}

The results of the present study show that adding cilazapril or metoprolol to amiodarone does not decrease the recurrence rates of $\mathrm{AF}$ after electrical cardioversion. Amiodarone and combination of these drugs were well tolerated by the patients.

Most of the AF recurrences are thought to be due to atrial electri- cal and structural remodeling that are partly mediated by RAS and autonomic nervous system $(3,10)$. AF leads to development of atrial fibrosis, which has been suggested to be responsible for electrophysiologic changes such as atrial conduction delay or reduced atrial effective refractory period (14).

Experimental animal studies showed the critical role of angiotensin II in both types of atrial remodeling in which histological and electrophysiological properties were reversed by ACE inhibition and angiotensin II blockade $(6,7)$. These findings were supported by clinical studies in which blockade of RAS with ACE inhibitor enalapril (8) or angiotensin II receptor antagonists irbesartan (9) as an adjunct to amiodarone facilitated sinus rhythm maintenance after cardioversion. Our results are in contrast with those findings. The present and previous studies differ in some aspects. First, in the previous studies $(8,9)$ the drugs were prescribed 4 weeks before, whereas our patients began to take the drugs in the day of electrical cardioversion. In persistent $\mathrm{AF}$, the effects of $\mathrm{ACE}$ inhibitors are thought to be mostly on structural, rather than electrical remodeling (15), which may need a sufficient period of time to exert their beneficial effects. However, we believe that one-year follow-up period in our study is long enough to observe the results of possible structural influences of cilazapril.
Secondly, in the study of Madrid et al. (9), there was a trend towards to higher beta blocker use in the irbesartan+amiodarone group than the amiodarone only group. So, co-administration of angiotensin II antagonists and beta blockers might have exerted synergistic effect on RAS and sympathetic nervous system, rather than RAS blockade only. Third, we used a different kind of ACE inhibitor, cilazapril. Studies investigating the effect of cilazapril on $\mathrm{AF}$ recurrence is limited. Recently, Li et al. demonstrated the supressive effect of cilazapril on atrial structural remodeling and the incidence of $\mathrm{AF}$ in dogs paced with high atrial rates (16). However, up to our knowledge, evidence lacks about the effect of cilazapril on AF recurrences in humans. Finally, atrial angiotensin II concentrations were found to be increased before plasma levels rised, suggesting in situ cardiac tissue synthesis as the source of atrial angiotensin II increases in an experimental model of atrial fibrillation in dogs (17). So, differences in the capability of blocking tissue RAS among ACE inhibitors may be responsible for the different results.

The other finding in the present study is the absence of any benefit of metoprolol on sinus rhythm maintanence. Van Noord et al. demonstrated that the beneficial effects of beta blockers in preventing AF relapse after cardioversion were 
more pronounced in the setting of hypertension rather than lone $\mathrm{AF}$ (18). The possible mechanism was suggested to be the lengthening of diastole, thereby decreasing atrial stretch related arrhythmogenicity. In our study, the spectrum of underlying heart diseases were similar among groups. Van Noord et al. also underscored the importance of initiating beta blocker therapy before the scheduled cardioversion, especially in terms of preventing earlier relapses (18). This was further pronounced by the study of Workman et al., in which atrial electrophysiological changes such as prolongation of atrial action potential duration and effective refractory period were suggested to be consistent with a long-term adaptive response, a type of "pharmacological remodeling", that appears as a result of long-term beta blockade (19). In the present study, beta blockers were not initiated before the scheduled cardioversion. In fact, others demonstrated that preventive effect of metoprolol from AF recurrence still persevered despite initiation on the day of cardioversion (12). However, none of the studies above (12, 18) used the combination of amiodarone and beta blocker together. So, amiodarone might have masked the effects of metoprolol on $\mathrm{AF}$ recurrences, in the present study.

In the present study neither cilazapril nor metoprolol were superior to each other. In the literature, the studies comparing ACE inhibitors and beta blockers after electrical cardioversion of AF is limited. In a large hypertension trial, blockade of RAS by angiotensin antagonist losartan had superior effects over the beta blocker atenolol in terms of reducing new onset AF (20). However, this study enrolled only the patients with left ventricular hypertrophy, a group of patients with more advanced hemodynamic abnormalities. As well, beta blockers are less effective in reducing hypertrophy and may be possibly less effective in preventing AF (21). The absence of any benefit of ACE inhibitors over beta blockers in terms of reducing new-onset $\mathrm{AF}$ in two other large hypertension trials $(22,23)$ partly supports our results. In fact, the two drugs act somewhat in a parallel manner. The possible mechanisms other than reversal of atrial remodeling, by which ACE inhibitors may exert antiarrhythmic effect include the decrease of wall stress, improvement of left ventricular function, decrease of left ventricular enddiastolic pressure and left atrial pressure, and modulation of ion currents and refractoriness (24). Beta blockers have also modulatory actions on ion channels (19), and they may be antiarrhythmic by lengthening diastole and enhancing ventricular filling, thereby ameliorating atrial-stretch (18). ACE inhibitors have beta-blocking properties, and beta blockers depress renin activity. Furthermore, structural and electrical remodeling, the two entities which ACE inhibitors and beta blockers are proposed to act on, are interrelated, in such a way that increases in atrial pressure have been shown to produce electrical remodeling, and prolonged rapid atrial rates can cause atrial dilatation (25).
This study has some limitations. First, the beginning time (at the time of cardioversion) of the drugs may be relatively late. This might effect the comparison of the recurrence rates in short-term, because longer time may be needed to exert their effects. However, our relatively long follow-up (one year) is thought to be enough to eliminate this problem at least in long-term. Secondly, we did not perform electrophysiological study or histological analysis for ethical reasons. These were performed previously in humans (26) and animals $(6,7)$. Finally, we did not evaluate possible paroxysmal AF attacks in our patients, so we might have missed asymptomatic episodes. However, our aim was to investigate recurrence of persistent $\mathrm{AF}$, not paroxysmal AF. We examined the patients at definite intervals or at any time they had symptoms to evaluate if there were any recurrences of persistent AF. So, we think that our methodology was sufficient for the aim of the study.

In conclusion, we could neither demonstrate any beneficial effect of concomitant use of cilazapril or metoprolol with amiodarone on cardioversion outcome in persistent AF. Our results may be important for that ACE inhibitors and beta blockers as an adjunct to amiodarone were compared with respect to their effect on sinus rhythm maintenance after electrical cardioversion of AF. Larger prospective, randomized, controlled trials with different drug combinations (eg. comparison of ACE inhibitors and beta blockers without amiodarone) are warranted.

\section{REFERENCES}

1. Birnie DH, Gollob M, Healey JS. Clinical trials, the renin angiotensin system and atrial fibrillation. Curr Opin Cardiol 2006;21:368-375.
2. Van Gelder IC, Crijns HJ, Van Gilst WH, et al. Prediction of uneventful cardioversion and maintenance of sinus rhythm from direct-current electrical cardioversion of chronic atrial fibrillation or atrial flutter. Am J Cardiol 1991;68:41-46.
3. Shiroshita-Takeshita A, Brundel BJJM, Nattel S. Atrial fibrillation: Basic mechanisms, remodeling and triggers. J Interv Card Electr 2005;13:181-193.

4. Mehta PK, Griendling KK. Angiotensin II 
cell signalling: Physiological and pathological effects in the cardiovascular system. Am J Physiol Cell Physiol 2007;292:C8297.

5. Goette A, Staack T, Röcken C, et al. Increased expression of extracellular signal-regulated kinase and angiotensin-converting enzyme in human atria during atrial fibrillation. J Am Coll Cardiol 2000;35:16691677.

6. Li D, Shinagawa K, Pang L, et al. Effects of angiotensin-converting enzyme inhibition on the development of the atrial fibrillation substrate in dogs with ventricular tachypacing-induced congestive heart failure. Circulation 2001;104:2608-2614

7. Nakashima H, Kumagai K, Urata H, et al Angiotensin II antagonist prevents electrical remodelling in atrial fibrillation. Circulation 2000;101:2612-2617.

8. Ueng KC, Tsai TP, Yu WC, et al. Use of enalapril to facilitate sinus rhythm maintenance after external cardioversion of long-standing persistent atrial fibrillation. Eur Heart J 2003;24:2090-2098.

9. Madrid AH, Bueno MG, Rebollo JMG, et al. Use of irbesartan to maintain sinus rhythm in patients with long-lasting persistent atrial fibrillation. Circulation 2002; 106:331-336

10. Lombardi F, Colombo A, Basilico B, et al Heart rate variability and early recurrence of atrial fibrillation after electrical cardioversion. J Am Coll Cardiol 2001;37:157 162 .

11. Tieleman RG, Van Gelder IC, Crijns HJGM, et al. Early recurrences of atrial fibrillation after electrical cardioversion: A result of fibrillation-induced electrical remodeling of the atria? J Am Coll Cardiol 1998;31:167-173.
12. Kühlkamp V, Schirdewan A, Stangl K, et al. Use of metoprolol CR/XL to maintain sinus rhythm after conversion from persistent atrial fibrillation. A randomized, double-blind, placebo-controlled study. J Am Coll Cardiol 2000;36:139-146.

13. Plewan A, Lehmann G, Ndrepepa G, et al. Maintenance of sinus rhythm after electrical cardioversion of persistent atrial fibrillation. Eur Heart J 2001;22:1504-1510.

14. Kalus JS, Coleman CI, White CM. The impact of supressing the renin-angiotensin system on atrial fibrillation. J Clin Pharmacol 2006; $46: 21-28$

15. Shinagawa $\mathrm{K}$, Mitamura $\mathrm{H}$, Ogawa $\mathrm{S}$, et al. Effects of inhibiting $\mathrm{Na}+/ \mathrm{H}+-$ Exchange or angiotensin converting enzyme on atrial tchycardia-induced remodeling. Cardiovasc Res 2002;54:438-446

16. Li Y, Li W, Gong Y, et al. The effects of cilazapril and valsartan on the mRNA and expressions of atrial calpains and atrial structural remodeling in atrial fibrillation in dogs. Basic Res Cardiol 2007; Feb 2 (Epub ahead of print)

17. Cardin S, Li D, Thorin-Trescases N, et al. Evolution of the atrial fibrllation substrate in experimental congestive heart failure: Angiotensin-dependent and -independent pathways. Cardiovasc Res 2003;60:315325.

18. Van Noord T, Tieleman RG, Bosker HA, et al. Beta-blockers prevent subacute recurrences of persistent atrial fibrillation only in patients with hypertension. Europace 2004;6:343-350.

19. Workman AJ, Kane KA, Russell JA, et al. Chronic beta-adrenoceptor blockade and human atrial cell electrophysiology: evidence of pharmacological remodeling. Cardiovasc Res 2003;58:518-525.
20. Wachtell K, Lehto M, Gerdts E, et al. Angiotensin II receptor blockade reduces new-onset atrial fibrillation and subsequent stroke compared to atenolol. The losartan intervention for end-point reduction in hypertension (LIFE) study. J Am Coll Cardiol 2005; $45: 712-719$.

21. Schmieder K, Sclaich MP, Klingbeil AU, et al. Update on reversal of left ventricular hypertrophy in essential hypertension (a meta-analysis of all randomized double-blind studies until December 1996). Nephrol Dial Transplant 1998;13:564569.

22. Hansson L, Lindholm LH, Ekborn T, et al Randomised trial of old and new antihypertensive drugs in elderly patients: cardiovascular mortality and morbidity the Swedish trial in Old Patients with Hypertension-2 study. Lancet 1999;354:17511756.

23. Hansson L, Lindholm LH, Niskanen L, et al. Effect of angiotensin-converting-enzyme inhibition compared with conventional therapy on cardiovascular morbidity and mortality in hypertension: the Captopril Prevention Project (CAPPP) randomised trial. Lancet 1999;353:611-616.

24. Ehrlich JR, Hohnloser SH, Nattel S. Role of angiotensin system and effects of its inhibition in atrial fibrillation: clinical and experimental evidence. Eur Heart J 2006;27:512-518

25. Healey JS, Morillo CA, Connolly SJ. Role of the renin-angiotensin-aldosterone system in atrial fibrillation and cardiac remodeling. Curr Opin Cardiol 2004;20:31-37.

26. Boldt A, Scholl A, Garbade J, et al. ACEinhibitor treatment attenuates atrial structural remodeling in patients with lone chronic atrial fibrillation. Basic Res Cardiol 2006;101:261-267. 